\title{
Gene Transcription Alterations Associated with Decrease of Ethanol Intake Induced by Naltrexone in the Brain of Wistar Rats
}

\author{
José M Oliva' and Jorge Manzanares*,2 \\ IInstitute of Physiological Chemistry and Pathobiochemistry, School of Medicine, Johannes-Gutemberg University of Mainz, Mainz, Germany; \\ ${ }^{2}$ Instituto de Neurociencias de Alicante, Universidad Miguel Hernandez-CSIC, San Juan de Alicante, Spain
}

\begin{abstract}
Preclinical and clinical studies suggest that the administration of the opioid antagonist naltrexone decreases the intake of ethanol. However, the neuroplastic adaptations in the brain associated to reduction of ethanol consumption remains to be elucidated. The aim of the study was to identify gene transcription alterations underlying the attenuation of voluntary ethanol intake by administration of naltrexone in rats. Increasing doses of naltrexone $(0.7 \mathrm{mg} / \mathrm{kg}$, 4 days and $1.4 \mathrm{mg} / \mathrm{kg} /$ day, 4 days $)$ to rats with acquired high preferring ethanol consumption ( $>3.5 \mathrm{~g}$ of ethanol $/ \mathrm{kg} /$ day) decreased voluntary ethanol intake (50\%). Voluntary ethanol consumption altered $\mu$ opioid receptor function in the cingulate cortex, caudate-putamen ( $\mathrm{CPu}$ ), nucleus accumbens core (Acb C) and shell (Acb S), the expression of tyrosine hydroxylase $(\mathrm{TH})$ in the ventral tegmental area and substantia nigra, proenkephalin (PENK) in the piriform cortex, olfactory tubercle, CPu, Acb C and Acb S, ventromedial nucleus (VMN) and paraventricular nucleus (PVN) of the hypothalamus, corticotropin releasing factor (CRF) in PVN, cannabinoid $C B_{1}$ receptor $\left(C B_{\mid}-R\right)$ in the $C P u$, hippocampus and $V M N$, and serotonin transporter (5-HTT) in the dorsal and median raphe nuclei. The reduction of ethanol intake induced by naltrexone was associated with a blockade or significant reduction of the changes produced by ethanol in the expression of these genes in key regions related to drug dependence. These results point to a role for the $\mu$-opioid receptor, TH, PENK, CRF, CB,-R, and 5-HTT genes in specific brain regions in the modulation of neuroadaptative mechanisms associated to the decrease of ethanol intake induced by naltrexone. Neuropsychopharmacology (2007) 32, 1358-1369. doi:I0.1038/sj.npp. I 301237; published online 25 October 2006
\end{abstract}

Keywords: naltrexone; ethanol; mRNA; cannabinoid; opioid; rat

\section{INTRODUCTION}

Alcoholism is a serious health, social, and familiar problem of difficult solution produced by the conjunction of different complex causes that reflect the interaction of genetic, environmental, socio-cultural, and personal factors (Saatcioglu et al, 2006). In general, the main objective in the treatment of alcohol dependence is the maintenance of the abstinence and the reduction of seeking behavior to avoid relapse. The development of alcohol dependence is a slow process produced by continuous and repeated consumption of ethanol that results specially damaging to subjects presenting high impulsivity, low self-esteem, and sensation-seeking behavior. The vulnerability to develop any kind of problems related to ethanol becomes even higher in

*Correspondence: Professor J Manzanares, Instituto de Neurociencias de Alicante, Universidad Miguel Hernandez-CSIC, Apartado de correos | 8, 03550 San Juan de Alicante, Spain, Tel: + 3496 59| 9248,

E-mail: jmanzanares@umh.es

Received 9 June 2006; revised 31 July 2006; accepted 4 August 2006 Online publication: 21 September 2006 at http://www.acnp.org/ citations/Npp092 106060382/default.pdf patients with certain psychiatric disorders such as phobias, attention-deficit hyperactive disorder or affective disorders (anxiety, depression, or bipolar disorder) (Hines et al, 2005). The reinforcing actions of ethanol are enhanced in these situations facilitating the progression to ethanol dependence. It has been proposed that consumption of ethanol stimulates dopamine neurons by acting directly on the nucleus accumbens and by disinhibiting GABA mesencephalic neurons projecting into the dopamine tegmental area (Spanagel and Weiss, 1999; Kienast and Heinz, 2006). Alterations in dopamine neurons in terminals (nucleus accumbens, cortex) and/or cell bodies (ventral tegmental area (VTA)) of mesolimbic and mesocortical systems lead to loss of neurochemical homeostatic control, contributing to the development of relapse and ethanol dependence (Flatscher-Bader et al, 2006). The disruption of dopaminergic neuronal activity in the nucleus accumbens is still considered one of the most important neurochemical targets underlying the initiation of impulse control diseases, however, drugs blocking dopamine receptors are not effective treatments of ethanol dependence patients. This idea suggests that the development of ethanol dependence 
may be the result of multiple neurochemical adaptations in the brain produced by the reinforcing actions of repeated consumption of ethanol in a number of circuits integrated with the reward system.

In the last years, the research in pharmacology has been intense with the hope to identify therapeutic agents that increase the efficacy of treatments of ethanol dependence. In fact, drugs such as naltrexone or acamprosate have been accepted as useful medications in the treatment of alcohol dependence and approved for clinical use. Naltrexone modulates the positive reinforcing properties of ethanol by blocking central opioid receptors and has proved its effectiveness in reducing ethanol consumption in laboratory animals (Bienkowski et al, 1999; Middaugh and Bandy, 2000; Cowen and Lawrence, 2001) and in humans (O'Malley et al, 1992; Volpicelli et al, 1992, 1995, 1997; O'Brien et al, 1996). Although these reports reflected behavioral modifications after naltrexone treatment, the neurochemical alterations associated to these changes remain to be determined. Indeed, the blockade of opioid receptors induced by naltrexone represents probably the initial mechanism that triggers a variety of 'neuroplastic adaptations' underlying the reduction of ethanol intake. A few reports indicated that the administration of naltrexone reverted the ethanol-induced increases in extracellular dopamine (Benjamin et al, 1993; Gonzales and Weiss, 1998; Inoue, 2000; Middaugh et al, 2003), or tyrosine hydroxylase $(\mathrm{TH})$ gene expression in the VTA (Lee et al, 2005), decreased the dopaminergic neuronal firing rates activated by ethanol (Inoue, 2000), induced changes in opioid receptor density (Parkes and Sinclair, 2000), and in proenkephalin (PENK) gene expression (Cowen and Lawrence, 2001).

The search of what enzymes or receptors are altered in animals made preferring for ethanol and, in particular, in those with significant decreased ethanol consumption after treatment with drugs as naltrexone may allow to find out potential pharmacological targets to treat more effectively ethanol dependence.

The purpose of this study was to identify what changes in the expression of a number of genes involved in the initiation or the maintenance of ethanol dependence are modified after treatment with naltrexone and in which specific brain regions of the rat are these alterations occurring. To this aim, TH, PENK, corticotropin releasing factor (CRF), cannabinoid $\mathrm{CB}_{1}$ receptor $\left(\mathrm{CB}_{1}-\mathrm{R}\right)$, and serotonin transporter (5-HTT) gene expression and $\mu$ opioid receptor functional autoradiography were examined in selected brain regions after naltrexone treatment in rats made preferring to ethanol.

\section{MATERIALS AND METHODS}

\section{Animals}

Male Wistar rats (275-300 g body weight) obtained from Harlan (Barcelona, Spain) were maintained in a temperature and light $\left(23 \pm 1^{\circ} \mathrm{C}\right.$, light on between 0800 and 2000 hours) controlled environment. Food and tap water were provided ad libitum. All experiments were performed following the standards of animal care in accordance to
National and International Laws for the Care and Use of Laboratory Animals.

\section{Ethanol Intake Protocol}

The experiment was divided in three phases: acquisition, maintenance, and treatment. The two-bottle choice paradigm of ethanol consumption was performed along the whole process. Initially, rats were randomly divided into following two groups: (1) 10 rats were submitted to unlimited access to water and (2) 90 rats were constantly exposed to two bottles containing either water or ethanol solutions. During the acquisition phase (12 days), in which animals acquire the ethanol intake behavior, the concentrations of ethanol were gradually increased $(2.5,5,7.5$, and $10 \% \mathrm{v} / \mathrm{v})$ every 3 days on the ethanol group. In the maintenance (15 days) and treatment ( 8 days) phases, the concentrations of ethanol were constantly maintained at $10 \%$. At the end of the maintenance phase, animals who reached $>3.0 \mathrm{~g}$ of ethanol $/ \mathrm{kg} / \mathrm{day}$ (as a minimum criterion) were selected and randomly divided into two groups to evaluate the naltrexone effectiveness to reduce the consumption of ethanol. In order to avoid positional preference intake of the ethanol, the bottles were interchanged in the box every day. The intake of water and ethanol were measured every 5 days during the maintenance phase and daily during the treatment phase. The results of ethanol consumption were expressed in $\mathrm{g}$ of ethanol/kg/day.

\section{Naltrexone Administration Protocol}

Rats previously selected at the end of maintenance phase were divided into two groups and were administered for a daily single i.p. administration of $0.7 \mathrm{mg} / \mathrm{kg}$ of naltrexone (4 days) followed by $1.4 \mathrm{mg} / \mathrm{kg}$ of naltrexone (4 days) $2 \mathrm{~h}$ before the dark period or equivalent volume of vehicle (saline). After this scalable treatment with naltrexone, rats were killed by decapitation and their brains were quickly removed, frozen over dry ice, and stored at $-80^{\circ} \mathrm{C}$.

\section{DAMGO-Stimulated $\left[{ }^{35} \mathrm{~S}\right] \mathrm{GTP} \gamma \mathrm{S}$ Binding Autoradiography}

Opioid $\mu$ receptor $\left[{ }^{35} \mathrm{~S}\right] \mathrm{GTP} \gamma \mathrm{S}$ binding was performed as described previously (Sim et al, 1996). Twelve micrometers brain sections at the level of caudate-putamen $(\mathrm{CPu})$ were mounted onto gelatin-coated slides and rinsed in assay buffer ( $50 \mathrm{mM}$ TRIS, $3 \mathrm{mM} \mathrm{MgCl}_{2}, 0.2 \mathrm{mM}$ EGTA, $100 \mathrm{mM}$ $\mathrm{NaCl}, \mathrm{pH} \mathrm{7.4)}$ at $25^{\circ} \mathrm{C}$ for $10 \mathrm{~min}$, then incubated with $2 \mathrm{mM}$ GDP in assay buffer for $30 \mathrm{~min}$ at $25^{\circ} \mathrm{C}$. Sections were then incubated for $2 \mathrm{~h}$ at $25^{\circ} \mathrm{C}$ in assay buffer with $0.04 \mathrm{nM}\left[{ }^{35} \mathrm{~S}\right]-$ $\mathrm{GTP} \gamma \mathrm{S}, 2 \mathrm{mM} \mathrm{GDP}$, and the $\mu$-opioid receptor agonist $7.5 \mu \mathrm{M}$ DAMGO. Basal activity was assessed in the absence of agonist, whereas nonspecific binding was measured in the presence of $10 \mu \mathrm{M}$ unlabeled GTP $\gamma$ S. Additional brain sections of the naive rats were incubated with $0.04 \mathrm{nM}$ $\left[{ }^{35} \mathrm{~S}\right] \mathrm{GTP} \gamma \mathrm{S}, 2 \mathrm{mM}$ GDP, DAMGO, and naltrexone $0.3 \mu \mathrm{M}$ to test for specificity of agonist receptor activation. After incubation, slides were rinsed twice in $50 \mathrm{mM}$ TRIS buffer, $\mathrm{pH} 7.4$, and once in cold deionized water, air-dried, and exposed to film (Kodak BioMax MR-1, Amersham Iberica, Madrid, Spain) for $36 \mathrm{~h}$. 


\section{In Situ Hybridization Histochemistry}

Brain sections were cut at $12 \mu \mathrm{m}$ at three different levels containing the regions of interest. The first level included the $\mathrm{CPu}$, accumbens core and shell nuclei (Acb C, Acb S), piriform cortex (Pir), and olfactory tubercle (Tu); the second level contained the paraventricular nucleus (PVN); the third level included the ventromedial nucleus (VMN) and the hippocampus fields (CA1, CA2, CA3, DG); the fourth level contained VTA and substantia nigra (SN) and the last level corresponded with the median and dorsal raphe nuclei (MnR, DR). All these sections were obtained according to Paxinos and Franklin Atlas (Paxinos and Watson, 1986), mounted onto gelatin-coated slides and stored at $-80^{\circ} \mathrm{C}$ until the day of the assay.

ISHH was performed as described previously (Young et al, 1986) using synthetic oligonucleotide probes complementary to TH mRNA (bases 1223-1252; Perkin Elmer, Pacisa-Giralt, Madrid, Spain), cannabinoid $\mathrm{CB}_{1}-\mathrm{R}$ mRNA (bases 4-51, 349-396, 952-999; Afigen, Madrid, Spain), CRF (bases 496-543; Perkin Elmer, Pacisa Giralt, Madrid, Spain), PENK (bases 388-435; Perkin Elmer, Pacisa-Giralt, Madrid, Spain), and 5-HTT (bases 77-126; Afigen, Madrid, Spain). Oligonucleotide probes were labeled using terminal deoxytransferase (Boehringer, Madrid, Spain) to add a ${ }^{35}$ S-labeled deoxyATP $\left(1000 \mathrm{Ci} \mathrm{mmol}^{-1}\right.$; Amersham, Madrid, Spain) tail to the $3^{\prime}$ end of the probes. The probe (in $50 \mu$ of hybridization buffer) was applied to each section and left overnight at $37^{\circ} \mathrm{C}$ for hybridization. Following hybridization, sections were washed four times for $15 \mathrm{~min}$ each in $0.15 \mathrm{M} \mathrm{NaCl}, 0.015 \mathrm{M}$ sodium citrate, $\mathrm{pH} 7.2$ $(1 \times$ saline sodium citrate, $\mathrm{SSC})$ at $55^{\circ} \mathrm{C}$, followed by two 30 min washes in $1 \times$ SSC at room temperature, one brief water dip, and were then blown dry with air. In order to control for imaging enhancement variables, each set of slides was apposed to the same film (Kodak BioMax MR-1, Amersham, Madrid, Spain) in individualized cassettes.

\section{Image Analyses Quantification}

In the autoradiograms from $\mu$-opioid-agonist-stimulated $\left[{ }^{35} \mathrm{~S}\right]$ GTP $\gamma S$ autoradiography, optical densities were calculated subtracting in each 'stimulated' measurement its corresponding 'basal' value, as previously shown (Corchero et al, 1999). The addition of naltrexone completely blocked the signal induced by DAMGO indicating that its effects in these experimental conditions are specific (data not shown).

Autoradiograms from in situ hybridization studies (two slides per level (two slices/slide; two measurements/slice) in each animal) were analyzed with a PC computer using the public domain NIH Image program (developed at the US National Institutes of Health and available on the Internet at http://rsb.info.nih.gov/nih-image). Previous experiments in our laboratory have found that the selected times of exposure to film, in these brains regions, and under our experimental conditions (oligonucleotide probe, radioactivity added to each slide, incubation conditions, type of film selected) renders a hybridization signal whose gray levels are linear with the optical density, according to the NIH Image Program. Therefore, optical densities were calculated from the uncalibrated mode of the Image Program by subtracting from each measurement its corresponding background and expressed in gray scale values. The background measurement was taken from an area of the slice with the lowest nonspecific hybridization signal and subtracted from the hybridization signal measurement in the same slice. Measurements were pooled from brain sections and the values were averaged. Results were presented considering mean control values as $100 \%$. Additional brain sections were cohybridized with a 100 fold excess of cold probes or with RNAse to assert the specificity of the signal. As expected, no hybridization signal was detected in these sections (data not shown).

\section{Statistical Analyses}

The analysis of drinking behavior was performed using a two-way analysis of variance (ANOVA) with repeated measures. The factors of variation were treatment and days of treatment as independent variables. Two-way ANOVA followed by Student-Newman-Keuls' test was performed for $\mu$-opioid binding autoradiography and in situ hybridization studies. Differences were considered significant when the probability of error was less than 5\%. SigmaStat software was used for all statistical analyses.

\section{RESULTS}

The behavioral data on ethanol intake were divided in three consecutives phases. At the beginning of the induction phase, the animals drink around $2.7 \mathrm{~g}$ of ethanol $/ \mathrm{kg} / \mathrm{day}$ during $2.5,5$, and $7.5 \%$ ethanol concentrations. However, when ethanol solution was changed to $10 \%$, animals reached levels of intake higher than $3.2 \mathrm{~g}$ ethanol $/ \mathrm{kg} /$ day. In the maintenance phase, the alcohol intake is kept constant around $3.5 \mathrm{~g}$ of ethanol/kg/day. The third phase corresponds to treatment with naltrexone using a scalable dosage administering $0.7 \mathrm{mg} / \mathrm{kg}$ (4 days) followed by a dose of $1.4 \mathrm{mg} / \mathrm{kg}$ (4 days). As shown in Figure 1, only the last administration of $0.7 \mathrm{mg} / \mathrm{kg}$ of naltrexone was effective to reduce the intake of ethanol. In addition, the second dosage of $1.4 \mathrm{mg} / \mathrm{kg}$ of naltrexone further decreased the consumption of ethanol between day 5 and day 8. A two-way repeated measures ANOVA was performed to evaluate differences in alcohol intake during the administration of naltrexone. The factors analyzed were doses of naltrexone, days of treatment, and the interaction ethanol $\times$ treatment between both factors. The results revealed significant differences in doses of naltrexone $\left(\mathrm{F}_{1,159}=40.54\right.$, $p<0.001)$, in days of treatment $\left(\mathrm{F}_{7,159}=5.43, p<0.001\right)$, and in the interaction doses $\times$ days $\left(\mathrm{F}_{7,159}=5.52, p<0.001\right)$.

Figure 2 shows the analysis of the $\mu$-opioid receptor function in several brain regions after ethanol intake and naltrexone treatment. The results after two-way ANOVA showed a lower DAMGO-stimulated $\left[{ }^{35} \mathrm{~S}\right]-\mathrm{GTP} \gamma \mathrm{S}$ binding levels in cingulate cortex $(\mathrm{Cg})(20 \%), \mathrm{CPu}(24 \%), \mathrm{Acb} \mathrm{C}$ (20\%), and Acb S (20\%). Treatment with naltrexone rendered to normal values the DAMGO-stimulated $\left[{ }^{35} \mathrm{~S}\right]-\mathrm{GTP} \gamma \mathrm{S}$ binding levels only in Acb S (ethanol $\mathrm{F}_{1,27}=$ 18.38, $p<0.001$; treatment $\mathrm{F}_{1,27}=8.17, p=0.009$; ethanol $\times$ treatment $\left.\mathrm{F}_{1,27}=7.469, p=0.012\right)$, whereas it was without effects on $\mathrm{Cg}$ (ethanol $\mathrm{F}_{1,27}=18.38, p<0.001$; treatment $\mathrm{F}_{1,27}=0.0005, p=0.984$; ethanol $\times$ treatment $\mathrm{F}_{1,27}=0.162$, 


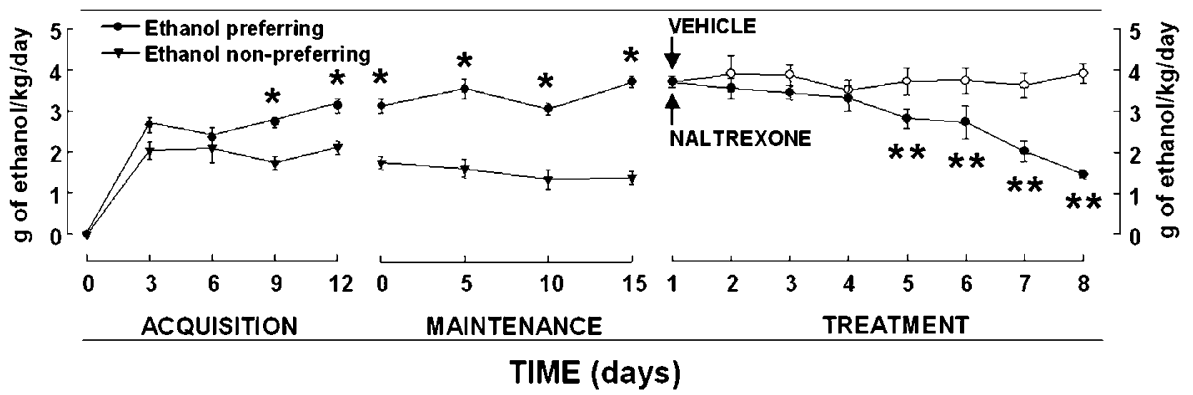

Figure I Ethanol intake levels in rats during acquisition, maintenance, and treatment phases. During the acquisition phase ( 12 days), the ethanol concentration was gradually increased $(2.5,5,7.5$, and $10 \% \mathrm{v} / \mathrm{v})$ every 3 days in the ethanol group. In the phases of maintenance (I5 days) and treatment, the ethanol concentration was constantly maintained at $10 \%$. At the end of the maintenance phase, animals reaching an intake of ethanol $>3.0 \mathrm{~g}$ of ethanol/ $\mathrm{kg} /$ day were selected, randomly divided into two groups and administered with a daily single i.p. administration of $0.7 \mathrm{mg} / \mathrm{kg}$ of naltrexone (4 days) followed by $1.4 \mathrm{mg} / \mathrm{kg}$ of naltrexone (4 days) $2 \mathrm{~h}$ before the dark period or equivalent volume of vehicle (saline) in vehicle animals. Symbols represent the means and vertical lines SEM of ethanol intake ( $g$ of ethanol $/ \mathrm{kg} / \mathrm{day}$ ). *Values from ethanol preferring animals that are significantly different $(p<0.05)$ from ethanol nonpreferring animals. $* *$ Values from naltrexone-treated animals that are significantly different $(p<0.05)$ from ethanol preferring animals.

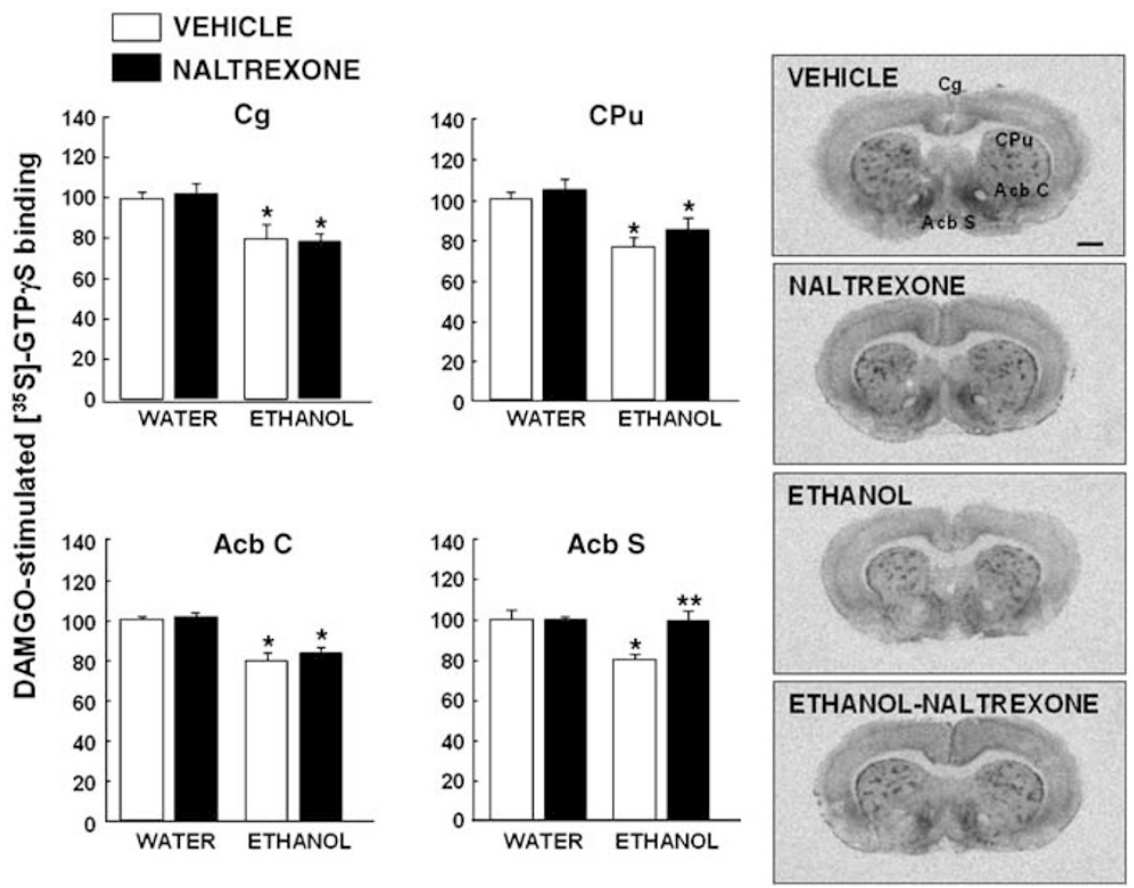

Figure 2 Effects of naltrexone and chronic ethanol intake on $\mu$-opioid receptor function in CPu, nucleus Acb C, nucleus Acb S, Cg. Columns represent the means and vertical lines SEM of DAMGO-stimulated-[ $\left.{ }^{35} \mathrm{~S}\right]-G T P \gamma S$ binding. *Values from ethanol- and naltrexone-treated animals that are significantly different $(p<0.05)$ from vehicle group. **Values from naltrexone-treated animals that are significantly different $(p<0.05)$ from ethanol animals. Representative autoradiograms of coronal brain sections at the level of $\mathrm{CPu}, \mathrm{Acb} \mathrm{C}, \mathrm{Acb} \mathrm{S}$, and $\mathrm{Cg}$ in rats treated with naltrexone, ethanol, or vehicle ( $\mathrm{V}$ ).

$p=0.691), \mathrm{CPu}$ (ethanol $\mathrm{F}_{1,27}=18.38, p<0.001$; treatment $\mathrm{F}_{1,27}=2.20, \quad p=0.151 ; \quad$ ethanol $\times$ treatment $\mathrm{F}_{1,27}=0.16$, $p=0.691$ ), or Acb C (ethanol $\mathrm{F}_{1,27}=18.38, \quad p<0.001$; treatment $\quad \mathrm{F}_{1,27}=0.001, \quad p=0.970 ; \quad$ ethanol $\times$ treatment $\left.\mathrm{F}_{1,27}=1.482, p=0.235\right)$. The autoradiograms in Figure 2 show the differences in $\mu$-opioid receptor functional activity in the rat brain regions analyzed after chronic ethanol consumption and/or naltrexone treatment.

The effects of chronic ethanol intake and treatment with naltrexone on TH gene expression in the VTA and SN are depicted in Figure 3. Two-way ANOVA revealed a significant increase in TH mRNA levels after ethanol intake in VTA $(23 \%)$ and SN (30\%) and a significant decrease after naltrexone administration in both brain regions suggesting a tendency to 'normalize' TH gene expression in both regions (VTA (ethanol $\mathrm{F}_{1,29}=38.53, p<0.010$, treatment $\mathrm{F}_{1,29}=4.37, \quad p=0.046$; ethanol $\times$ interaction $\mathrm{F}_{1,29}=2.45$, $p=0.130$ ); $\mathrm{SN}$ (ethanol $\mathrm{F}_{1,29}=108.05, p<0.001$; treatment $\mathrm{F}_{1,29}=6.42, \quad p=0.018 ; \quad$ ethanol $\times$ treatment, $\quad \mathrm{F}_{1,29}=2.70$, $p=0.112)$ ). No differences were found between vehicle and naltrexone groups. In the lower part of Figure 3 representative autoradiograms of coronal brain sections of vehicle, ethanol and naltrexone groups show the differences in TH gene expression in VTA and SN.

The alterations induced in PENK gene expression by ethanol and naltrexone are dependent on the brain region examined (Figure 4). Two-way ANOVA showed a significant decrease on PENK mRNA levels in the ethanol group in $\mathrm{CPu}$ 
(25\%), Acb C (40\%), Acb S (56\%), Tu (20\%), and VMN $(10 \%)$, whereas a marked increase $(60 \%)$ was detected in PVN. Treatment with naltrexone reversed, at least in part, the decrease of PENK mRNA levels found in $\mathrm{CPu}(10 \%)$ and in Acb C (15\%) and Tu. However, the administration with

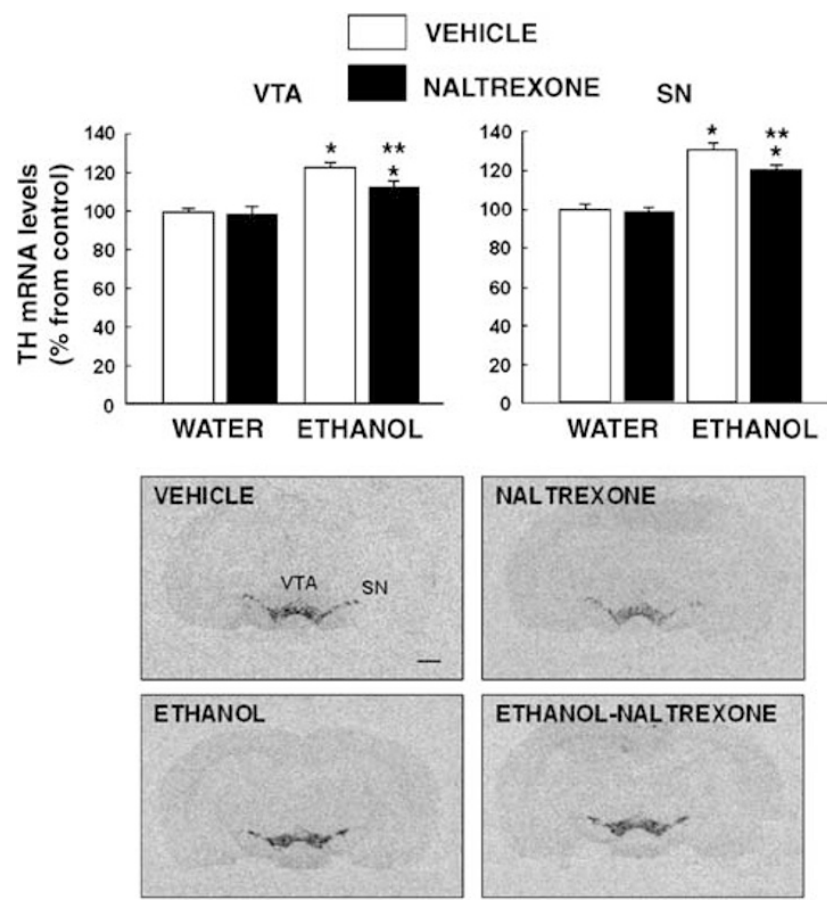

Figure 3 Effects of naltrexone and chronic ethanol administration on $\mathrm{TH}$ gene expression in the VTA and SN. Columns represent the means and vertical lines SEM of TH mRNA levels. *Values from ethanol preferring animals and naltrexone-treated animals that are significantly different $(p<0.05)$ from vehicle-treated animals. $* *$ Values from naltrexone-treated animals that are significantly different $(p<0.05)$ from ethanol animals. Representative autoradiograms of coronal brain sections at the level of VTA and SN in rats treated with naltrexone, ethanol, or vehicle. Bar represents I $\mathrm{mm}$. naltrexone was unable to block the effects of ethanol intake in Acb S, VMN, or PVN $\left(\mathrm{CPu}\right.$ (ethanol $\mathrm{F}_{1,34}=27.07$, $p<0.001$; treatment $\mathrm{F}_{1,34}=1.35, p=0.256$; ethanol $\times$ treatment $\mathrm{F}_{1,34}=2.99, p=0.094$ ); Acb $\mathrm{C}$ (ethanol $\mathrm{F}_{1,34}=39.13$, $p<0.001$; treatment $\mathrm{F}_{1,34}=0.19, p=0.665$; ethanol $\times$ treatment $\mathrm{F}_{1,34}=8.67, p=0.006$ ); Acb $\mathrm{S}$ (ethanol $\mathrm{F}_{1,38}=13.09$, $p<0.001$; treatment $\mathrm{F}_{1,38}=4.89, p=0.034$; ethanol $\times$ treatment $\mathrm{F}_{1,38}=8.08, p=0.007$ ); Tu (ethanol $\mathrm{F}_{1,33}=5.40$, $p<0.027$; treatment $\mathrm{F}_{1,33}=3.71, p=0.064$; ethanol $\times$ treatment, $\mathrm{F}_{1,33}=0.187, p=0.668$ ); $\mathrm{PVN}$ (ethanol $\mathrm{F}_{1,26}=108.44$, $p<0.001$; treatment $\mathrm{F}_{1,26}=0.939, p=0.343$; ethanol $\times$ treatment $\mathrm{F}_{1,26}=0.746, p=0.397$ ); VMN (ethanol $\mathrm{F}_{1,31}=17.98$, $p<0.001$; treatment $\mathrm{F}_{1,31}=0.204, p=0.655$; ethanol $\times$ treatment $\mathrm{F}_{1,31}=0.053, p=0.820$ ); Ce (ethanol $\mathrm{F}_{1,32}=89.38$, $p<0.001$; treatment $\mathrm{F}_{1,32}=10.01, p=0.004$; ethanol $\times$ treatment $\left.F_{1,32}=5.679, p=0.024\right)$ ). No significant alterations in PENK gene expression were found in ethanol, treatment, and interaction ethanol $\times$ treatment in Pir (ethanol $\mathrm{F}_{1,23}=0.44, p=0.513 ;$ treatment $\mathrm{F}_{1,23}=0.85, p=0.368$; interaction $\mathrm{F}_{1,23}=0.39, p=0.539$ ). No differences were found between vehicle and naltrexone groups. Autoradiograms of coronal brain sections representative of all the experimental groups showing the differences in hybridization signal of PENK mRNA levels in the regions analyzed after chronic ethanol 10\% intake and naltrexone $0.7-1.4 \mathrm{mg} /$ $\mathrm{kg}$ treatment are depicted in Figure 5.

As shown in Figure 6, two-way ANOVA revealed that CRF mRNA levels in the PVN appeared significantly increased after chronic ethanol (28\%). The administration of naltrexone not only blocked this increase but also decreased (20\%) CRF gene expression compared to vehicle-treated group (ethanol $\mathrm{F}_{1,21}=0.661, p=0.427$; treatment $\mathrm{F}_{1,21}=22.54$, $p<0.001$; ethanol $\times$ treatment $\left.\mathrm{F}_{1,21}=20.24, p<0.001\right)$. The lower panels of Figure 6 contain representative autoradiograms of coronal brain sections at the level of the PVN showing differences in the hybridization signal of CRF gene expression induced by chronic ethanol intake and treatment with naltrexone.
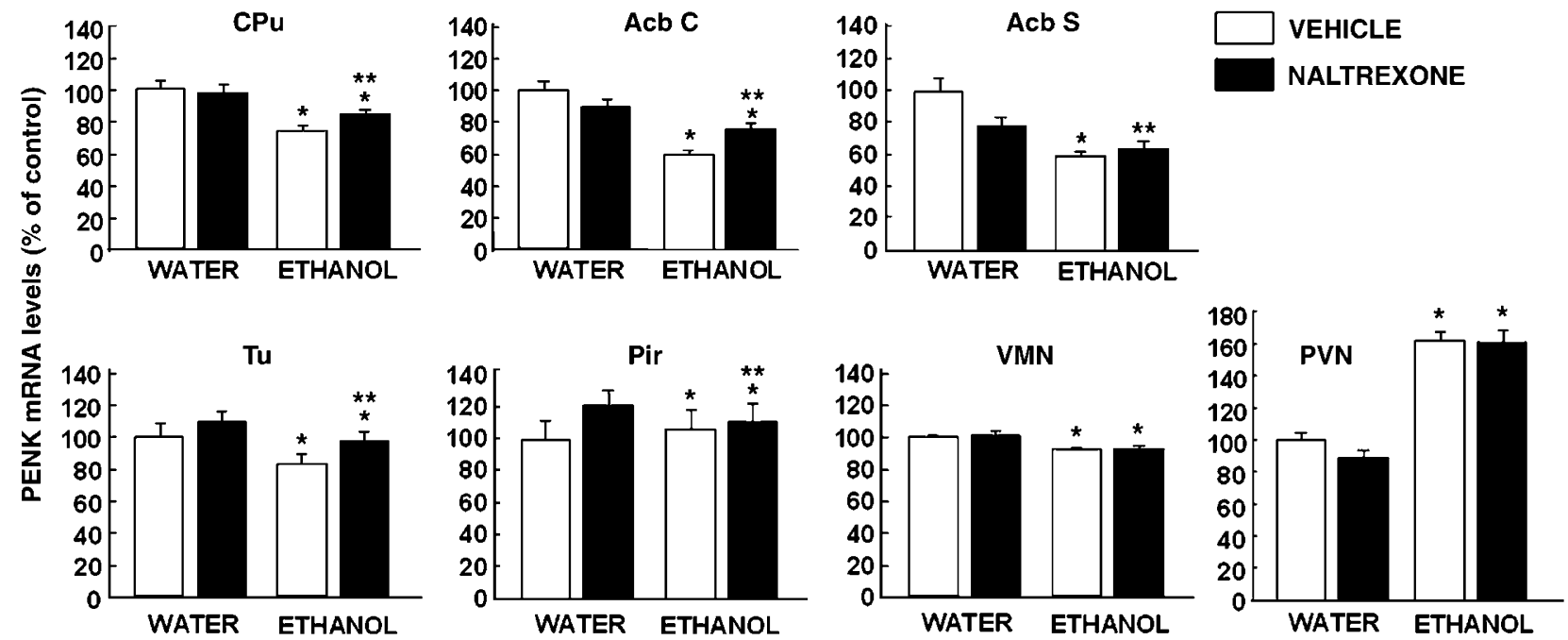

Figure 4 Effects of naltrexone and chronic ethanol administration on PENK gene expression in CPu, Acb C, Acb S, olfactory Tu, Pir, VMN of the hypothalamus, and PVN of the hypothalamus. Columns represent the means and vertical lines SEM of PENK mRNA levels. *Values from ethanol preferring animals and naltrexone-treated animals that are significantly different $(p<0.05)$ from vehicle-treated animals. **Values from naltrexone-treated animals that are significantly different $(p<0.05)$ from ethanol animals. 


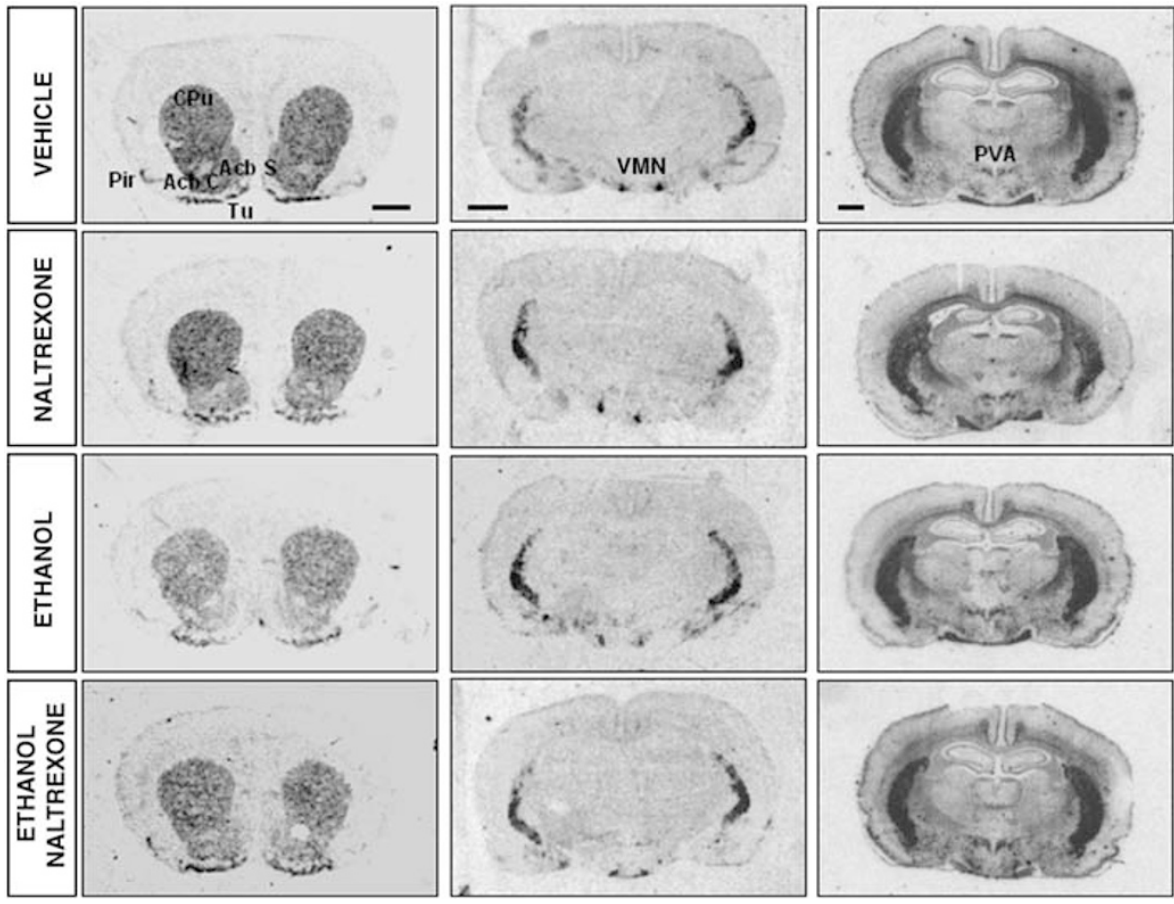

Figure 5 Representative autoradiograms of PENK mRNA levels on coronal brain sections at the level of CPu, Acb C, Acb S, Tu, Pir, VMN, and PVN in rats treated with naltrexone, ethanol, or vehicle. Bar represents $1 \mathrm{~mm}$.

The effects of chronic ethanol intake and treatment with naltrexone on cannabinoid $\mathrm{CB}_{1}-\mathrm{R}$ gene expression in several brain regions are shown in Figure 7. The two-way ANOVA analysis revealed that intake of ethanol produced a significant increase on $\mathrm{CB}_{1}-\mathrm{R}$ gene expression in $\mathrm{CPu}$ (35\%), VMN (17\%), and DG (33\%), whereas treatment with naltrexone blocked these effects $\left(\mathrm{CPu}\right.$ (ethanol $\mathrm{F}_{1,31}=14.61$, $p<0.001$; treatment $\mathrm{F}_{1,31}=22.38, p<0.001$; ethanol $\times$ treatment $\mathrm{F}_{1,31}=31.36, p<0.001$ ); VMN (ethanol $\mathrm{F}_{1,32}=8.06$, $p=0.008$; treatment $\mathrm{F}_{1,32}=6.41, p=0.017$; ethanol $\times$ treatment $F_{1,32}=1.58, p=0.218$ ); DG (ethanol $F_{1,31}=22.90$, $p<0.001$; treatment $\mathrm{F}_{1,31}=4.31, p=0.047$; ethanol $\times$ treatment $\left.\mathrm{F}_{1,31}=3.189, p=0.085\right)$ ). These results are in contrast with those observed in hippocampus fields (CA1, CA2, CA3). Chronic intake of ethanol decreased $(20 \%) C_{1}-R$ gene expression in CA1 whereas was without effects in CA2 and CA3 fields. The treatment with naltrexone did not alter the effects of ethanol in any of these regions of the hippocampus (CA1 (ethanol $\mathrm{F}_{1,31}=46.18, p<0.001$; treatment $\quad \mathrm{F}_{1,31}=5.67, \quad p=0.024$; ethanol $\times$ treatment $\mathrm{F}_{1,31}=0.58, p=0.454$ ); CA2 (ethanol $\mathrm{F}_{1,31}=0.08, p=0.928$; treatment $\quad \mathrm{F}_{1,31}=2.03, \quad p=0.165 ; \quad$ ethanol $\times$ treatment $\mathrm{F}_{1,31}=0.90, p=0.350$ ); $\mathrm{CA} 3$ (ethanol $\mathrm{F}_{1,31}=7.37, p=0.011$; treatment $\quad \mathrm{F}_{1,31}=0.97, \quad p=0.333$; ethanol $\times$ treatment $\left.\mathrm{F}_{1,31}=0.03, p=0.85\right)$ ). Figure 8 shows the differences in hybridization signal corresponding to $\mathrm{CB}_{1}-\mathrm{R}$ gene expression in the brain regions studied after consumption of ethanol and treatment with naltrexone.

Figure 9 shows the effects of chronic ethanol intake and treatment with naltrexone on 5-HTT gene expression in the raphe nuclei. The two-way ANOVA analysis revealed that 5-HTT mRNA levels significantly increased after chronic ethanol in MnR (72\%) and DR (25\%) and naltrexone reduced (21\%) in MnR and fully blocked the effects of ethanol in DR (MnR (ethanol $\mathrm{F}_{1,26}=55.74, p<0.001$; treatment $\quad \mathrm{F}_{1,26}=0.41, \quad p=0.529 ; \quad$ ethanol $\times$ treatment $\mathrm{F}_{1,26}=5.29, p=0.031$ ); $\mathrm{DR}$ (ethanol $\mathrm{F}_{1,24}=6.82, p=0.016$; treatment $\quad \mathrm{F}_{1,24}=77.52, \quad p<0.001 ; \quad$ ethanol $\times$ treatment $\left.\mathrm{F}_{1,24}=33.37, p<0.001\right)$ ). In the lower part of Figure 9 are depicted representative autoradiograms of coronal brain sections at the levels of $\mathrm{MnR}$ and $\mathrm{DR}$ showing the differences of ethanol intake and the treatment with naltrexone in the hybridization signal due to 5-HTT gene expression.

\section{DISCUSSION}

The results of this study provide new evidences of the 'neuroplastic' adaptations produced by prolonged consumption of ethanol in rats made preferring for ethanol and identify key proteins in specific brain regions underlying the decrease of ethanol intake after treatment with naltrexone. The type of experimental design to induce preference for ethanol consumption using the 'two bottles system' may be considered as an animal model of 'problems related to excessive consumption of alcohol'. After an acquisition phase of 12 days followed by a maintenance phase of 2 more weeks, rats were selected on the basis of an intake of ethanol $>3.0 \mathrm{~g} / \mathrm{kg} / \mathrm{day}$. In these 4 weeks, the consumption of ethanol achieved a stable pattern that makes a treatment with naltrexone appropriated. The results of scalable doses of naltrexone $0.7 \mathrm{mg} / \mathrm{kg}$ for 4 days followed by an additional period of 4 days at $1.4 \mathrm{mg} / \mathrm{kg}$ revealed a significant decrease in the consumption of ethanol, in particular, in the last days of treatment (approximately $50 \%$ ). The decrease of ethanol consumption after treatment with naltrexone has been shown by different 


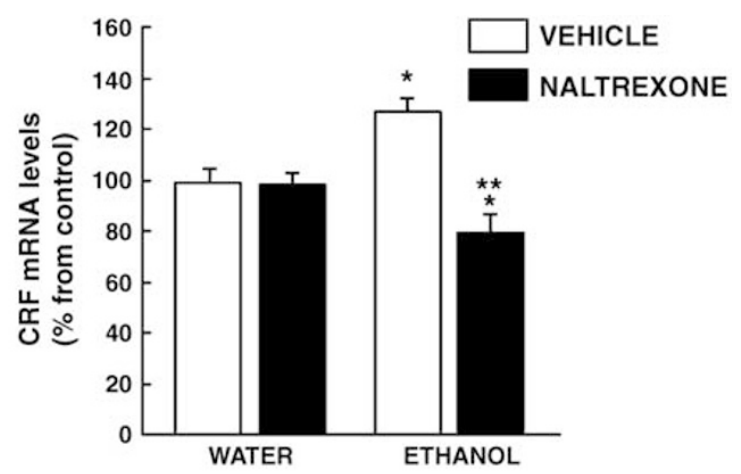

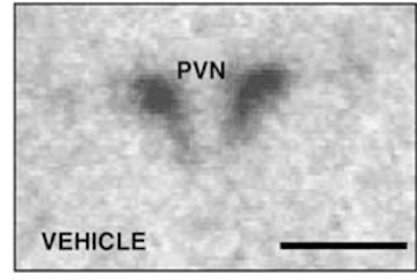
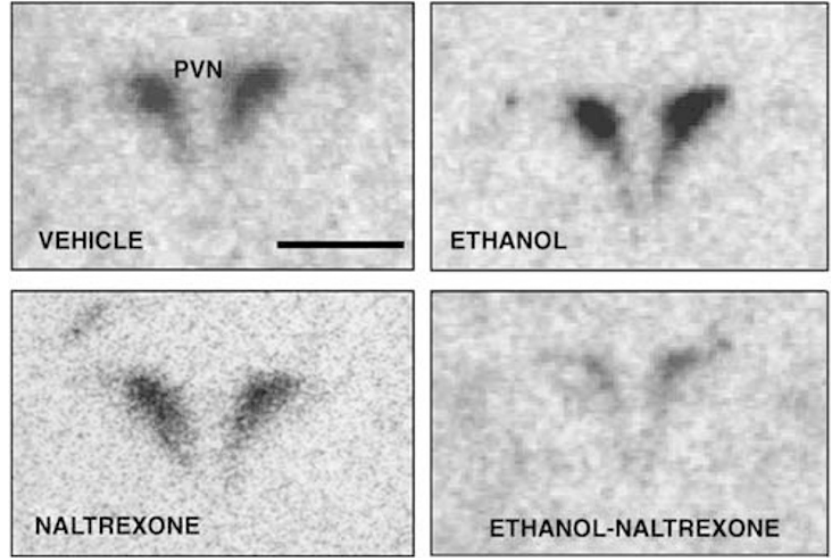

Figure 6 Effects of naltrexone and chronic ethanol administration on CRF gene expression in the PVN. Columns represent the means and vertical lines SEM of CRF mRNA levels. *Values from ethanol preferring animals and naltrexone-treated animals that are significantly different $(p<0.05)$ from vehicle-treated animals. ***Values from naltrexone-treated animals that are significantly different $(p<0.05)$ from ethanol animals. Representative autoradiograms of coronal brain sections at the level of the PVN in rats treated with naltrexone, ethanol, or vehicle. Bar represents $1 \mathrm{~mm}$. laboratories although the magnitude of the reduction in consumption is variable and may depend of the experimental design, the strain of the rat, the duration of the treatment, and the dose employed or the length of the period that rats have been drinking ethanol before initiating the treatment (Benjamin et al, 1993; Myers and Lankford, 1996; Davidson and Amit, 1997; Phillips et al, 1997; Bienkowski et al, 1999; Goodwin et al, 2001; Stromberg et al, 2001, 2002). In this study, the prolonged consumption of ethanol in rats selected by its preference produced a significant decrease in the functional activity of $\mu$-opioid receptors in $\mathrm{Cg}, \mathrm{CPu}, \mathrm{Acb} \mathrm{C}$, and Acb $\mathrm{S}$. The reduction in $\mu$-opioid-stimulated $\left[{ }^{35} \mathrm{~S}\right] \mathrm{GTP} \gamma$ binding in prefrontal cortex induced by voluntary ethanol intake was reported previously (Sim-Selley et al, 2002), although no differences were found in $\mathrm{Cg}, \mathrm{CPu}$, or nucleus accumbens. The reasons that may account for this discrepancy may be related with the fact that these authors used sucrose, a higher concentration of ethanol $(15 \% \mathrm{v} / \mathrm{v})$ than the present study and sessions of $20 \mathrm{~min}$ from Monday to Friday, whereas we allowed permanent ethanol consumption without sucrose and at a lower concentration of ethanol $(10 \% \mathrm{v} / \mathrm{v})$. The $\mu$-opioid receptor has been considered for a long time a key element related with increased vulnerability to ethanol consumption, the development of ethanol dependence and relapse, and therefore as one of the most important therapeutic targets to control ethanol dependence and craving (Manzanares et al, 2005). Differences in $\mu$-opioid receptor densities were reported in rats presenting high and low preference for ethanol consumption (Cowen et al, 1999; Fadda et al, 1999; Sim-Selley et al, 2002). In addition, mice lacking the $\mu$-opioid receptor do not self-administer ethanol (Roberts et al, 2000). These findings in animal models of alcohol consumption are consistent with clinical studies showing alterations in $\mu$-opioid receptors in detoxified alcoholics (Heinz et al, 2005) or with a functional

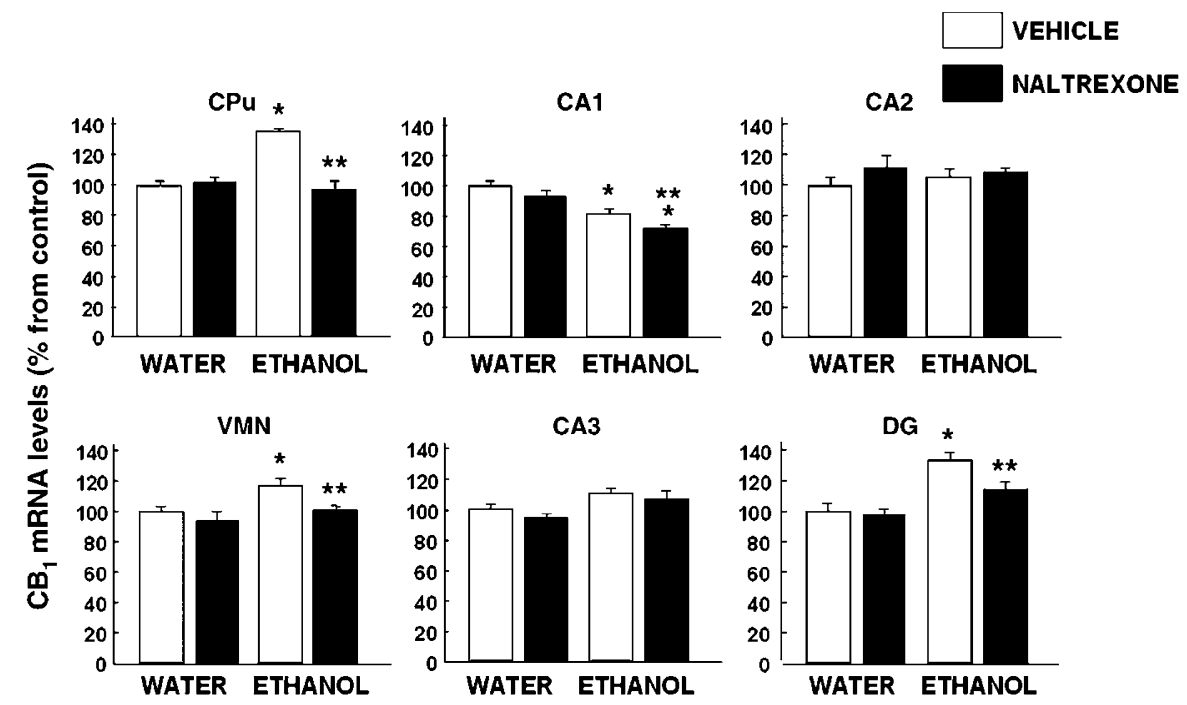

Figure 7 Effects of naltrexone and chronic ethanol administration on cannabinoid CB,-R gene expression in CPu, hippocampus fields (CAI, CA2, CA3), $D G$, and $V M N$. Columns represent the means and vertical lines $S E M$ of $C B_{1}-R$ mRNA levels. *Values from ethanol preferring animals and naltrexone-treated animals that are significantly different $(p<0.05)$ from vehicle-treated animals. **Values from naltrexone-treated animals that are significantly different $(p<0.05)$ from ethanol animals. 


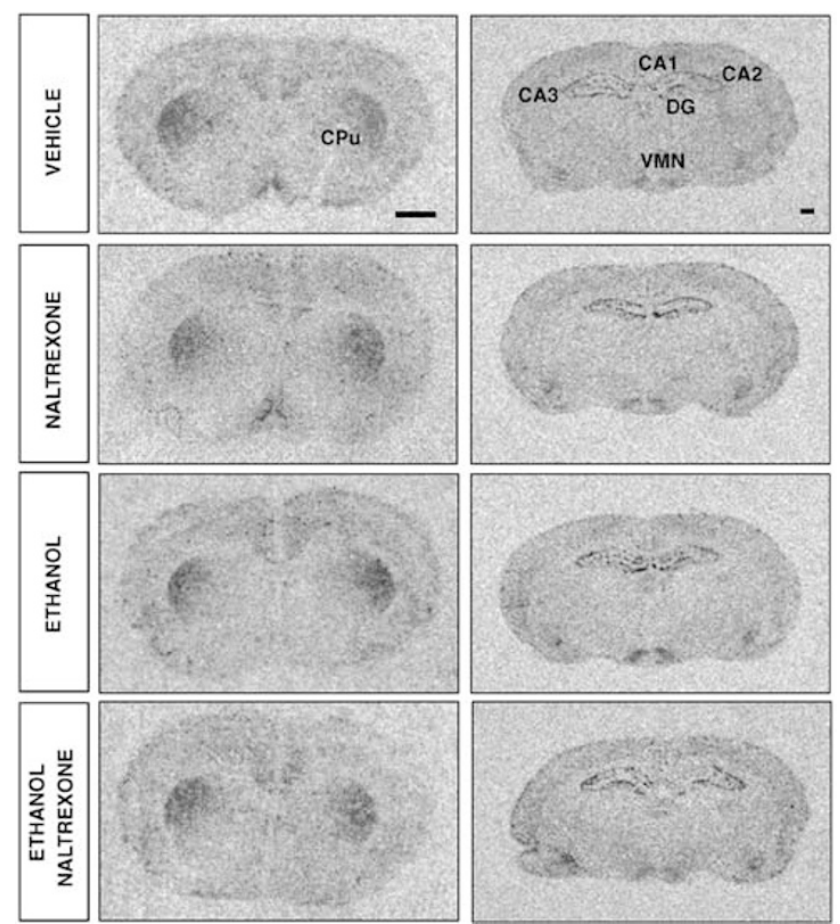

Figure 8 Representative autoradiograms of cannabinoid $C_{1}$, mRNA levels on coronal brain sections at the level of CPu, CAI, CA2, CA2, CA3, and $\mathrm{VMN}$ in rats treated with naltrexone, ethanol, or vehicle. Bar represents $1 \mathrm{~mm}$.

polymorphism of the $\mu$-opioid receptor gene associated with naltrexone response in alcohol-dependent patients (Oslin et al, 2003).

The administration of naltrexone at the doses used in this study failed to alter $\mu$-opioid receptor functional activity in any of the brain regions examined of water drinking animals. However, this preferential $\mu$-opioid antagonist completely blocked the decrease of $\mu$-opioid receptor functional activity induced by ethanol found in the Acb S. These results identify, for the first time, the shell part of the nucleus accumbens as the region where a 'normalization' of $\mu$-opioid receptors correlates to a substantial reduction of ethanol consumption after treatment with naltrexone. The precise molecular mechanisms by which naltrexone decreased ethanol consumption are complex and still remain to be elucidated. Considering the results found in this study, it is tempting to speculate that the blockade of $\mu$-opioid receptors, in particular in the Acb $S$, may impede the action of increased release of $\beta$-endorphins by ethanol, reducing as a consequence the desire of ethanol consumption. It is interesting to mention that a recent study by Ward (Ward et al, 2006) suggests this accumbal region as the one mediating behaviors in self-administration of foods and perhaps valued substances as ethanol or other drugs of abuse.

For several years, a large body of evidence has pointed the mesolimbic dopaminergic system as the circuit most closely involved in the positive reinforcing properties of natural reward stimuli and drug of abuse such as ethanol (Robbins et al, 1989; Robbins and Everitt, 1996; Spanagel and Weiss, 1999). In this study, the results clearly showed that a 4 -week consumption of ethanol increased TH gene expression in

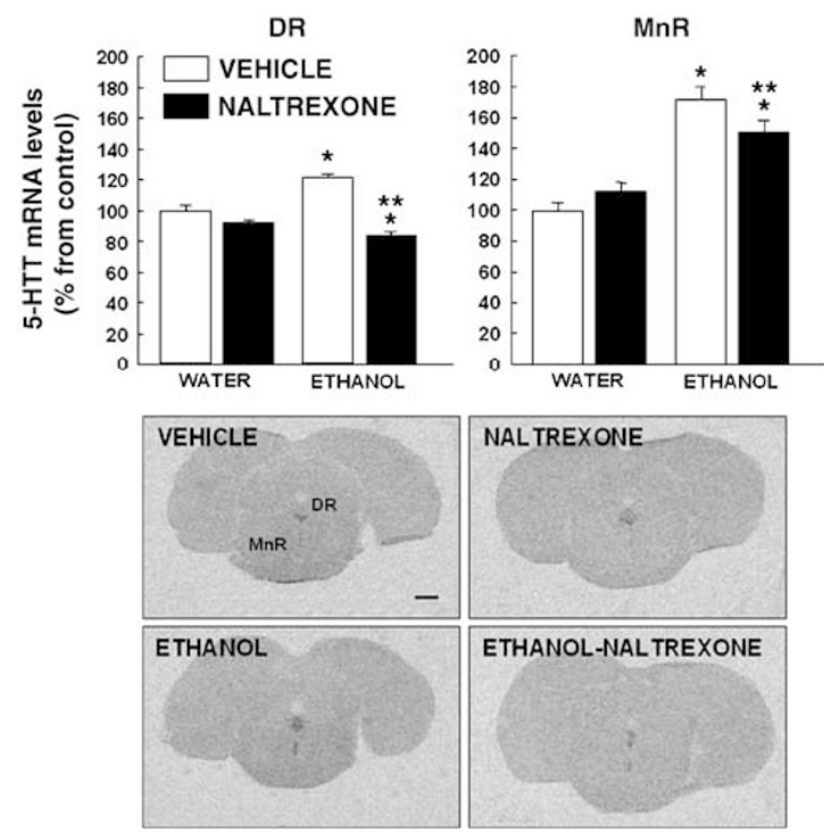

Figure 9 Effects of naltrexone and chronic ethanol administration on 5-HTT gene expression in the DR and MnR nuclei. Columns represent the means and vertical lines SEM of 5-HTT mRNA levels. *Values from ethanol preferring animals and naltrexone-treated animals that are significantly different $(p<0.05)$ from vehicle-treated animals. $* *$ Values from naltrexone-treated animals that are significantly different $(p<0.05)$ from ethanol animals. Representative autoradiograms of coronal brain sections at the level of DR and $M n R$ in rats treated with naltrexone, ethanol, or vehicle. Bar represents $1 \mathrm{~mm}$.

VTA and SN. These increases are fully blocked after treatment with naltrexone suggesting mesolimbic and nigrostriatal circuits as important systems that correlate with decreased intake of ethanol. Previous studies have suggested that naltrexone reduced the ethanol-induced increase in dialysate dopamine levels in the nucleus accumbens (Benjamin et al, 1993; Gonzales and Weiss, 1998; Middaugh et al, 2003) or dopamine neuronal firing rates activated by ethanol (Inoue, 2000). It is important to note that in these reports the release of dopamine was blocked by acute naltrexone administration. The only study to date which has examined the expression of TH in VTA and $\mathrm{SN}$ after several weeks of ethanol consumption, has found that chronic naltrexone administration attenuated the ethanol-induced increase in cell bodies of mesolimbic dopaminergic pathway (Lee et al, 2005). These findings further support the results of the present study suggesting that the 'normalization' of gene expression in the VTA is clearly involved in the decrease of ethanol consumption induced by treatment with naltrexone. However, drugs acting directly at dopamine receptors or blocking the dopamine transporter have not been approved yet for clinical use for the treatment of ethanol dependence. In this respect, it is also interesting to hypothesize that this dopaminergic circuit would be more involved in the rapid and first reinforcing actions of ethanol, that is, triggering the initiation of a complex neurochemical process whereas the endogenous opioid system as well as other neuropeptide systems may be considered the support of the maintenance of the drug abuse dependence. 
In this study, prolonged ethanol consumption produced a significant decrease in PENK gene expression in brain regions integrating a reward circuit, that includes $\mathrm{CPu}, \mathrm{Acb}$ $\mathrm{C}$, Acb $\mathrm{S}$, and $\mathrm{Tu}$, closely involved in the reinforcement actions of ethanol, whereas markedly increased PENK mRNA levels in the PVN of the hypothalamus. Consistent with these results, a previous report showed decreases in PENK gene expression in the nucleus accumbens and olfactory $\mathrm{Tu}$ and increases in the amygdala after several weeks of ethanol consumption (Cowen and Lawrence, 2001). The relevance of the role of this opioid gene in ethanol dependence is also strengthened by the fact that basal lower PENK gene expression has been related to high vulnerability for ethanol consumption (Gianoulakis et al, 1996; Fadda et al, 1999; Marinelli et al, 2000; Cowen and Lawrence, 2001; Manzanares et al, 2005). Treatment with naltrexone tended to 'normalize' the decreases found in the reward circuit regions whereas no effects were observed in the PVN. These results suggest that naltrexone was effective on the desire of consumption of ethanol but failed to block the 'anxiogenic' component of repeated ethanol intake as reflected by a $60 \%$ increase in PENK gene expression in the PVN.

Exposure to stressful environmental manipulations has been related with increased vulnerability to drug abuse consumption, development of dependence, and high risk to relapse (Piazza and Le Moal, 1996). In addition, several reports indicated that acute and chronic consumption of ethanol clearly upregulates CRF gene expression in the PVN of the hypothalamus (Rivier et al, 1990; Rivier and Lee, 1996; Liu and Weiss, 2002; Lack et al, 2005; Li et al, 2005). In agreement with these previous reports, in this study prolonged consumption of ethanol increased the expression of the CRF gene. Interestingly, the administration of naltrexone fully blocked the increase induced by ethanol suggesting that 'normalization' of CRF gene expression in the PVN of the hypothalamus relates to decrease of ethanol consumption. The precise molecular mechanisms by which the administration of naltrexone may regulate the expression of CRF remains to be further examined. However, it is possible to hypothesize that consumption of ethanol would increase the release of opioid peptides, which in turn would stimulate the secretion of hypothalamic pituitary axis hormones and therefore the expression of the precursor gene CRF. Blockade of opioid receptors by administration of naltrexone may partially block these actions reducing as a consequence the expression of CRF. These results further suggest that CRF may be considered an interesting target to control ethanol dependence. Indeed, it is tempting to speculate that the administration of CRF antagonists together with naltrexone may result synergistic in the reduction of ethanol consumption, although further studies are needed to determine the validity of this potential pharmacological association.

In recent years, a large body of evidence points to the endogenous cannabinoid $\mathrm{CB}_{1}-\mathrm{R}$ as a relevant target involved in the vulnerability and development of ethanol consumption (Hungund and Basavarajappa, 2000; Basavarajappa and Hungund, 2002; Hungund et al, 2003; Wang et al, 2003; Naassila et al, 2004; Ortiz et al, 2004a, b; Houchi et al, 2005; Manzanares et al, 2005). Furthermore, several reports suggest that blockade of the $\mathrm{CB}_{1}-\mathrm{R}$ decreases the intake of ethanol drinking in different animal models (Rodriguez de Fonseca et al, 1999; Lallemand et al, 2001, 2004; Cippitelli et al, 2005; Colombo et al, 2005; Gessa et al, 2005; Economidou et al, 2006). The results of this study revealed that a 4-week consumption of ethanol increased $\mathrm{CB}_{1}-\mathrm{R}$ in $\mathrm{CPu}, \mathrm{VMN}$, and $\mathrm{DG}$ of the hippocampus. In contrast, previous studies in our laboratory (Ortiz et al, 2004b) reported decreases in $\mathrm{CB}_{1}-\mathrm{R}$ in several brain regions. The reasons that may explain these differences may be related with the fact that in this previous study we used forced consumption of ethanol with sucrose and the duration of exposure was more prolonged (52 days). Probably, the effects of forced or voluntary ethanol consumption may differentially affect the function of $\mathrm{CB}_{1-}$ R. Further studies are being carried out to clarify this issue. The administration of naltrexone did not alter $\mathrm{CB}_{1}-\mathrm{R}$ gene expression in water drinking rats but fully blocked the increase induced by ethanol suggesting that the recovery of normal levels of gene expression may be also associated to reduction of ethanol consumption. The mechanisms by which the blockade of the opioid receptor modulate the expression of $\mathrm{CB}_{1}-\mathrm{R}$ remain to be further explored. It is interesting to note, however, that an interaction between opioid and cannabinoid systems has previously reported (for a review see Manzanares et al, 1999, 2005) and that concurrent treatment with opioid and cannabinoid receptor antagonists resulted in synergistic action to reduce ethanol consumption (Gallate et al, 2004). Taken together, these results suggest that the manipulation of both receptors may be a new therapeutic alternative to reduce craving and to control the reduction of consumption in ethanol-dependent patients. Controlled clinical trials should be carried out to test this hypothesis.

A large number of reports related genetic and functional alterations in the 5-HTT with the occurrence of depressionand anxiety-related disorders associated to alcohol dependence (Heinz et al, 1998, 2000; Turker et al, 1998; Mantere et al, 2002; Oroszi and Goldman, 2004). Indeed, the manipulation of the 5-HTT by treatment with selective serotonin reuptake inhibitors (SSRI) has resulted beneficial to decrease consumption in animal models of alcohol dependence and in patients presenting alcohol dependence together with depressive- and or anxiety-like symptoms (Murphy et al, 1985; Naranjo and Sellers, 1989; Naranjo et al, 1994; Gulley et al, 1995; Maurel et al, 1999; Naranjo and Knoke, 2001; Kelai et al, 2003). The results if this study revealed that consumption of ethanol significantly increased 5-HTT gene expression in the DR and MnR. The administration of naltrexone failed to alter the expression of 5HTT in water drinking animals but significantly blocked the increases induced in ethanol drinking rats, suggesting that the return of the expression of this gene to 'normal' levels may be associated to decrease of ethanol consumption induced by naltrexone. As repeated treatment with SSRI would tend to downregulate the 5-HTT gene, considering the results found in this study, it is possible to hypothesize that concurrent administration of naltrexone and SSRI may result synergistic in this action and therefore may further decrease the consumption of ethanol, not necessarily in depressive alcoholic patients. Further clinical studies are required to test this hypothesis. Although the mechanism by which naltrexone affects 5-HTT gene in ethanol drinking 
rats is still unknown, a recent report by our laboratory suggests that treatment with an SSRI as fluoxetine decreased endogenous opioid gene expression in brain regions associated to reward (Oliva et al, 2005). Blockade of opioid receptors by naltrexone may presumably alter opioid gene expression, which in turn would modify the functional activity of 5-HTT gene. Further studies are being carried out to analyze this issue.

In conclusion, this study reveals that development of preference and high consumption of ethanol produces a number of 'neuroplastic' adaptations that include the $\mu$ opioid receptor, TH, PENK, CRF, $\mathrm{CB}_{1}-\mathrm{R}$, and 5-HTT in various brain regions of the rat. Interestingly, the decrease of ethanol consumption after treatment with naltrexone is accompanied by a full blockade or a high tendency to return to normal values several alterations previously induced in these genes. It is important to point out that treatment with naltrexone do not simply decreased the gene expression levels induced by ethanol consumption, as this drug failed to alter mRNA levels in control animals. Therefore, the results of this study strongly suggest that naltrexone is contributing to normalize the neuroplastic changes induced by the consumption of ethanol. Therefore, it may be proposed that the decrease of consumption produced by treatment with naltrexone requires a 'readaptation' in those genes that have been modified by the ethanol. Furthermore, the results of this study reveal that drugs designed to 'stabilize' these genes may be potentially beneficial to treat ethanol dependence.

\section{REFERENCES}

Basavarajappa BS, Hungund BL (2002). Neuromodulatory role of the endocannabinoid signaling system in alcoholism: an overview. Prostaglandins Leukot Essent Fatty Acids 66: 287-299.

Benjamin D, Grant ER, Pohorecky LA (1993). Naltrexone reverses ethanol-induced dopamine release in the nucleus accumbens in awake, freely moving rats. Brain Res 621: 137-140.

Bienkowski P, Kostowski W, Koros E (1999). Ethanol-reinforced behaviour in the rat: effects of naltrexone. Eur J Pharmacol 374: 321-327.

Cippitelli A, Bilbao A, Hansson AC, del Arco I, Sommer W, Heilig $M$ et al (2005). Cannabinoid CB1 receptor antagonism reduces conditioned reinstatement of ethanol-seeking behavior in rats. Eur J Neurosci 21: 2243-2251.

Colombo G, Serra S, Vacca G, Carai MA, Gessa GL (2005). Endocannabinoid system and alcohol addiction: pharmacological studies. Pharmacol Biochem Behav 81: 369-380.

Corchero J, Romero J, Berrendero F, Fernandez-Ruiz J, Ramos JA, Fuentes JA et al (1999). Time-dependent differences of repeated administration with Delta9-tetrahydrocannabinol in proenkephalin and cannabinoid receptor gene expression and G-protein activation by mu-opioid and CB1-cannabinoid receptors in the caudate-putamen. Brain Res Mol Brain Res 67: 148-157.

Cowen MS, Lawrence AJ (2001). Alterations in central preproenkephalin mRNA expression after chronic free-choice ethanol consumption by fawn-hooded rats. Alcohol Clin Exp Res 25: 1126-1133.

Cowen MS, Rezvani AH, Jarrott B, Lawrence AJ (1999). Ethanol consumption by Fawn-Hooded rats following abstinence: effect of naltrexone and changes in mu-opioid receptor density. Alcohol Clin Exp Res 23: 1008-1014.

Davidson D, Amit Z (1997). Naltrexone blocks acquisition of voluntary ethanol intake in rats. Alcohol Clin Exp Res 21: 677-683.
Economidou D, Mattioli L, Cifani C, Perfumi M, Massi M, Cuomo $\mathrm{V}$ et al (2006). Effect of the cannabinoid CB1 receptor antagonist SR-141716A on ethanol self-administration and ethanol-seeking behaviour in rats. Psychopharmacology (Berlin) 183: 394-403.

Fadda P, Tronci S, Colombo G, Fratta W (1999). Differences in the opioid system in selected brain regions of alcohol-preferring and alcohol-nonpreferring rats. Alcohol Clin Exp Res 23: 1296-1305.

Flatscher-Bader T, Van der Brug MP, Landis N, Hwang JW, Harrison E, Wilce PA (2006). Comparative gene expression in brain regions of human alcoholics. Genes Brain Behav 5(Suppl 1): 78-84.

Gallate JE, Mallet PE, McGregor IS (2004). Combined low dose treatment with opioid and cannabinoid receptor antagonists synergistically reduces the motivation to consume alcohol in rats. Psychopharmacology (Berlin) 173: 210-216.

Gessa GL, Serra S, Vacca G, Carai MA, Colombo G (2005). Suppressing effect of the cannabinoid CB1 receptor antagonist, SR147778, on alcohol intake and motivational properties of alcohol in alcohol-preferring sP rats. Alcohol Alcohol 40: 46-53.

Gianoulakis C, de Waele JP, Thavundayil J (1996). Implication of the endogenous opioid system in excessive ethanol consumption. Alcohol 13: 19-23.

Gonzales RA, Weiss F (1998). Suppression of ethanol-reinforced behavior by naltrexone is associated with attenuation of the ethanol-induced increase in dialysate dopamine levels in the nucleus accumbens. J Neurosci 18: 10663-10671.

Goodwin FL, Campisi M, Babinska I, Amit Z (2001). Effects of naltrexone on the intake of ethanol and flavored solutions in rats. Alcohol 25: 9-19.

Gulley JM, McNamara C, Barbera TJ, Ritz MC, George FR (1995). Selective serotonin reuptake inhibitors: effects of chronic treatment on ethanol-reinforced behavior in mice. Alcohol 12: $177-181$.

Heinz A, Jones DW, Mazzanti C, Goldman D, Ragan P, Hommer D et al (2000). A relationship between serotonin transporter genotype and in vivo protein expression and alcohol neurotoxicity. Biol Psychiatry 47: 643-649.

Heinz A, Ragan P, Jones DW, Hommer D, Williams W, Knable MB et al (1998). Reduced central serotonin transporters in alcoholism. Am J Psychiatry 155: 1544-1549.

Heinz A, Reimold M, Wrase J, Hermann D, Croissant B, Mundle G et al (2005). Correlation of stable elevations in striatal mu-opioid receptor availability in detoxified alcoholic patients with alcohol craving: a positron emission tomography study using carbon 11-labeled carfentanil. Arch Gen Psychiatry 62: 57-64.

Hines LM, Ray L, Hutchison K, Tabakoff B (2005). Alcoholism: the dissection for endophenotypes. Dialogues Clin Neurosci 7: 153-163.

Houchi H, Babovic D, Pierrefiche O, Ledent C, Daoust M, Naassila M (2005). CB1 receptor knockout mice display reduced ethanolinduced conditioned place preference and increased striatal dopamine D2 receptors. Neuropsychopharmacology 30: 339-349.

Hungund BL, Basavarajappa BS (2000). Distinct differences in the cannabinoid receptor binding in the brain of C57BL/6 and DBA/ 2 mice, selected for their differences in voluntary ethanol consumption. J Neurosci Res 60: 122-128.

Hungund BL, Szakall I, Adam A, Basavarajappa BS, Vadasz C (2003). Cannabinoid CB1 receptor knockout mice exhibit markedly reduced voluntary alcohol consumption and lack alcohol-induced dopamine release in the nucleus accumbens. J Neurochem 84: 698-704.

Inoue $H$ (2000). Effects of naltrexone on the accumulation of L-3, 4-dihydroxyphenylalanine and 5-hydroxy-L-tryptophan and on the firing rate induced by acute ethanol administration. Eur $J$ Pharmacol 406: 375-380.

Kelai S, Aissi F, Lesch KP, Cohen-Salmon C, Hamon M, Lanfumey L (2003). Alcohol intake after serotonin transporter inactivation in mice. Alcohol Alcohol 38: 386-389. 
Kienast T, Heinz A (2006). Dopamine and the diseased brain. CNS Neurol Disord Drug Targets 5: 109-131.

Lack AK, Floyd DW, McCool BA (2005). Chronic ethanol ingestion modulates proanxiety factors expressed in rat central amygdala. Alcohol 36: 83-90.

Lallemand F, Soubrie P, De Witte P (2004). Effects of CB1 cannabinoid receptor blockade on ethanol preference after chronic alcohol administration combined with repeated re-exposures and withdrawals. Alcohol Alcohol 39: 486-492.

Lallemand F, Soubrie PH, De Witte PH (2001). Effects of CB1 cannabinoid receptor blockade on ethanol preference after chronic ethanol administration. Alcohol Clin Exp Res 25: 1317-1323.

Lee YK, Park SW, Kim YK, Kim DJ, Jeong J, Myrick H et al (2005). Effects of naltrexone on the ethanol-induced changes in the rat central dopaminergic system. Alcohol Alcohol 40: 297-301.

Li Z, Kang SS, Lee S, Rivier C (2005). Effect of ethanol on the regulation of corticotropin-releasing factor (CRF) gene expression. Mol Cell Neurosci 29: 345-354.

Liu X, Weiss F (2002). Additive effect of stress and drug cues on reinstatement of ethanol seeking: exacerbation by history of dependence and role of concurrent activation of corticotropin-releasing factor and opioid mechanisms. J Neurosci 22: 7856-7861.

Mantere T, Tupala E, Hall H, Sarkioja T, Rasanen P, Bergstrom K et al (2002). Serotonin transporter distribution and density in the cerebral cortex of alcoholic and nonalcoholic comparison subjects: a whole-hemisphere autoradiography study. Am J Psychiatry 159: 599-606.

Manzanares J, Corchero J, Romero J, Fernandez-Ruiz JJ, Ramos JA, Fuentes JA (1999). Pharmacological and biochemical interactions between opioids and cannabinoids. Trends Pharmacol Sci 20: $287-294$.

Manzanares J, Ortiz S, Oliva JM, Perez-Rial S, Palomo T (2005). Interactions between cannabinoid and opioid receptor systems in the mediation of ethanol effects. Alcohol Alcohol 40: $25-34$.

Marinelli PW, Kiianmaa K, Gianoulakis C (2000). Opioid propeptide mRNA content and receptor density in the brains of AA and ANA rats. Life Sci 66: 1915-1927.

Maurel S, De Vry J, Schreiber R (1999). Comparison of the effects of the selective serotonin-reuptake inhibitors fluoxetine, paroxetine, citalopram and fluvoxamine in alcohol-preferring cAA rats. Alcohol 17: 195-201.

Middaugh LD, Bandy AL (2000). Naltrexone effects on ethanol consumption and response to ethanol conditioned cues in C57BL/6 mice. Psychopharmacology (Berlin) 151: 321-327.

Middaugh LD, Szumlinski KK, Van Patten Y, Marlowe AL, Kalivas PW (2003). Chronic ethanol consumption by C57BL/6 mice promotes tolerance to its interoceptive cues and increases extracellular dopamine, an effect blocked by naltrexone. Alcohol Clin Exp Res 27: 1892-1900.

Murphy JM, Waller MB, Gatto GJ, McBride WJ, Lumeng L, Li TK (1985). Monoamine uptake inhibitors attenuate ethanol intake in alcohol-preferring (P) rats. Alcohol 2: 349-352.

Myers RD, Lankford MF (1996). Suppression of alcohol preference in high alcohol drinking rats: efficacy of amperozide versus naltrexone. Neuropsychopharmacology 14: 139-149.

Naassila M, Pierrefiche O, Ledent C, Daoust M (2004). Decreased alcohol self-administration and increased alcohol sensitivity and withdrawal in CB1 receptor knockout mice. Neuropharmacology 46: 243-253.

Naranjo CA, Knoke DM (2001). The role of selective serotonin reuptake inhibitors in reducing alcohol consumption. J Clin Psychiatry 62(Suppl 20): 18-25.

Naranjo CA, Poulos CX, Bremner KE, Lanctot KL (1994). Fluoxetine attenuates alcohol intake and desire to drink. Int Clin Psychopharmacol 9: 163-172.
Naranjo CA, Sellers EM (1989). Serotonin uptake inhibitors attenuate ethanol intake in problem drinkers. Recent Dev Alcohol 7: 255-266.

O'Brien CP, Volpicelli LA, Volpicelli JR (1996). Naltrexone in the treatment of alcoholism: a clinical review. Alcohol 13: 35-39.

Oliva JM, Uriguen L, Perez-Rial S, Manzanares J (2005). Time course of opioid and cannabinoid gene transcription alterations induced by repeated administration with fluoxetine in the rat brain. Neuropharmacology 49: 618-626.

O'Malley SS, Jaffe AJ, Chang G, Schottenfeld RS, Meyer RE, Rounsaville B (1992). Naltrexone and coping skills therapy for alcohol dependence. A controlled study. Arch Gen Psychiatry 49: 881-887.

Oroszi G, Goldman D (2004). Alcoholism: genes and mechanisms. Pharmacogenomics 5: 1037-1048.

Ortiz S, Oliva JM, Perez-Rial S, Palomo T, Manzanares J (2004a). Differences in basal cannabinoid CB1 receptor function in selective brain areas and vulnerability to voluntary alcohol consumption in Fawn Hooded and Wistar rats. Alcohol Alcohol 39: 297-302.

Ortiz S, Oliva JM, Perez-Rial S, Palomo T, Manzanares J (2004b). Chronic ethanol consumption regulates cannabinoid CB1 receptor gene expression in selected regions of rat brain. Alcohol Alcohol 39: 88-92.

Oslin DW, Berrettini W, Kranzler HR, Pettinati H, Gelernter J, Volpicelli JR et al (2003). A functional polymorphism of the $\mathrm{mu}$-opioid receptor gene is associated with naltrexone response in alcohol-dependent patients. Neuropsychopharmacology 28: 1546-1552.

Parkes H, Sinclair JD (2000). Reduction of alcohol drinking and upregulation of opioid receptors by oral naltrexone in AA rats. Alcohol 21: 215-221.

Paxinos G, Watson C (1986). The Rat Brain in Stereotaxic Coordinates. Academic Press, Harcourt Brace Jovanovich: New York.

Phillips TJ, Wenger CD, Dorow JD (1997). Naltrexone effects on ethanol drinking acquisition and on established ethanol consumption in C57BL/6J mice. Alcohol Clin Exp Res 21: 691-702.

Piazza PV, Le Moal ML (1996). Pathophysiological basis of vulnerability to drug abuse: role of an interaction between stress, glucocorticoids, and dopaminergic neurons. Annu Rev Pharmacol Toxicol 36: 359-378.

Rivier C, Imaki T, Vale W (1990). Prolonged exposure to alcohol: effect on CRF mRNA levels, and CRF- and stress-induced ACTH secretion in the rat. Brain Res 520: 1-5.

Rivier C, Lee S (1996). Acute alcohol administration stimulates the activity of hypothalamic neurons that express corticotropinreleasing factor and vasopressin. Brain Res 726: 1-10.

Robbins TW, Cador M, Taylor JR, Everitt BJ (1989). Limbic-striatal interactions in reward-related processes. Neurosci Biobehav Rev 13: $155-162$

Robbins TW, Everitt BJ (1996). Neurobehavioural mechanisms of reward and motivation. Curr Opin Neurobiol 6: 228-236.

Roberts AJ, McDonald JS, Heyser CJ, Kieffer BL, Matthes HW, Koob GF et al (2000). mu-Opioid receptor knockout mice do not self-administer alcohol. J Pharmacol Exp Ther 293: 1002-1008.

Rodriguez de Fonseca F, Roberts AJ, Bilbao A, Koob GF, Navarro M (1999). Cannabinoid receptor antagonist SR141716A decreases operant ethanol self administration in rats exposed to ethanol-vapor chambers. Zhongguo Yao Li Xue Bao 20: $1109-1114$.

Saatcioglu O, Erim R, Cakmak D (2006). Role of family in alcohol and substance abuse. Psychiatry Clin Neurosci 60: 125-132.

Sim LJ, Selley DE, Dworkin SI, Childers SR (1996). Effects of chronic morphine administration on mu opioid receptorstimulated $\left[{ }^{35} \mathrm{~S}\right] \mathrm{GTPgammaS}$ autoradiography in rat brain. J Neurosci 16: 2684-2692. 
Sim-Selley LJ, Sharpe AL, Vogt LJ, Brunk LK, Selley DE, Samson $\mathrm{HH}$ (2002). Effect of ethanol self-administration on mu- and delta-opioid receptor-mediated G-protein activity. Alcohol Clin Exp Res 26: 688-694.

Spanagel R, Weiss F (1999). The dopamine hypothesis of reward: past and current status. Trends Neurosci 22: 521-527.

Stromberg MF, Mackler SA, Volpicelli JR, O’Brien CP (2001). Effect of acamprosate and naltrexone, alone or in combination, on ethanol consumption. Alcohol 23: 109-116.

Stromberg MF, Sengpiel T, Mackler SA, Volpicelli JR, O’Brien CP, Vogel WH (2002). Effect of naltrexone on oral consumption of concurrently available ethanol and cocaine in the rat. Alcohol 28: 169-179.

Turker T, Sodmann R, Goebel U, Jatzke S, Knapp M, Lesch KP et al (1998). High ethanol tolerance in young adults is associated with the low-activity variant of the promoter of the human serotonin transporter gene. Neurosci Lett 248: 147-150.

Volpicelli JR, Alterman AI, Hayashida M, O'Brien CP (1992). Naltrexone in the treatment of alcohol dependence. Arch Gen Psychiatry 49: 876-880.
Volpicelli JR, Rhines KC, Rhines JS, Volpicelli LA, Alterman AI, O'Brien CP (1997). Naltrexone and alcohol dependence. Role of subject compliance. Arch Gen Psychiatry 54: 737-742.

Volpicelli JR, Volpicelli LA, O’Brien CP (1995). Medical management of alcohol dependence: clinical use and limitations of naltrexone treatment. Alcohol Alcohol 30: 789-798.

Wang L, Liu J, Harvey-White J, Zimmer A, Kunos G (2003). Endocannabinoid signaling via cannabinoid receptor 1 is involved in ethanol preference and its age-dependent decline in mice. Proc Natl Acad Sci USA 100: 1393-1398.

Ward HG, Nicklous DM, Aloyo VJ, Simansky KJ (2006). Mu-opioid receptor cellular function in the nucleus accumbens is essential for hedonically driven eating. Eur J Neurosci 23: $1605-1613$

Young III WS, Bonner TI, Brann MR (1986). Mesencephalic dopamine neurons regulate the expression of neuropeptide mRNAs in the rat forebrain. Proc Natl Acad Sci USA 83: 9827-9831. 